\title{
Selective effects of a short transient environmental fluctuation on a natural population
}

\author{
Markus Pfenninger ${ }^{1,2,3}$, Quentin Foucault ${ }^{1}$, Ann-Marie Waldvogel ${ }^{4}$, Barbara Feldmeyer ${ }^{1}$ \\ ${ }^{1}$ Dept. Molecular Ecology, Senckenberg Biodiversity and Climate Research Centre, Georg-Voigt-Str. \\ 14-16, D-60325, Frankfurt am Main, Germany
}

${ }^{2}$ LOEWE Centre for Translational Biodiversity Genomics, Senckenberg Biodiversity and Climate Research Centre, Senckenberganlage 25, 60325 Frankfurt am Main, Germany

${ }^{3}$ Institute for Molecular and Organismic Evolution, Johannes Gutenberg University, Johann-JoachimBecher-Weg 7, 55128, Mainz, Germany

${ }^{4}$ Dept. Ecological Genomics, Institute of Zoology, University of Cologne, Zülpicherstr. 47b, 50674 Köln, Germany

Keywords

Genotype-phenotype map, fluctuating selection, selective tracking

Abstract

Natural populations experience continuous and often transient changes of environmental conditions. These in turn may result in fluctuating selection pressures leading to variable demographic and evolutionary population responses. Rapid adaptation as short-term response to a sudden environmental change has in several cases been attributed to polygenic traits, but the underlying genomic dynamics and architecture are poorly understood. In this study, took advantage of a natural experiment in an insect population by monitoring genome-wide allele frequencies before and after a cold snap event. Whole genome pooled sequencing of time series samples revealed ten selected haplotypes carrying ancient polymorphisms, partially with signatures of balancing selection. By constantly cold exposing genetically variable individuals in the laboratory, we could demonstrate with whole genome resequencing i) among the survivors, the same alleles rose in frequency as in the wild and ii) that the identified variants additively predicted fitness (survival time) of its bearers. Finally, by simultaneously sequencing the genome and the transcriptome of cold exposed individuals we could tentatively link some of the selected SNPs to the cis- and trans-regulation of genes and pathways known to be involved in cold response of insects, like Cytochrome P450 and fatty acid metabolism. Altogether, our results shed light on the strength and speed of selection in natural populations and the genomic architecture of its underlying polygenic trait. Population genomic time series data thus appear as promising tool for measuring the selective tracking of fluctuating selection in natural populations.

\section{Introduction}

Adaptation in natural populations occurs when selection acts on variable phenotypic traits with a heritable basis. There is a general agreement that selection in the wild is intense (Hoekstra et al., 2001; Kingsolver et al., 2001). It is also variable in space and time (Bell, 2010; Price, Grant, Gibbs, \& Boag, 1984; Siepielski, DiBattista, Evans, \& Carlson, 2011), even though there is some debate whether changes in the direction of selection are frequent or not (Kingsolver, Diamond, Siepielski, \& Carlson, 2012; Kingsolver \& Pfennig, 2007; Siepielski, DiBattista, \& Carlson, 2009). Recent theoretical (Messer \& Petrov, 2013) and empirical work (Bitter, Kapsenberg, Gattuso, \& Pfister, 2019) has shown that selection in natural populations can lead to rapid adaptation, in particular of polygenic traits 
bioRxiv preprint doi: https://doi.org/10.1101/2022.02.10.479864; this version posted February 10, 2022. The copyright holder for this preprint (which was not certified by peer review) is the author/funder, who has granted bioRxiv a license to display the preprint in perpetuity. It is made available under aCC-BY-NC-ND 4.0 International license.

(Barghi, Hermisson, \& Schlötterer, 2020; Jain \& Stephan, 2017). If the rate of environmental change is not too fast and the population characteristics allows for effective selection, adaptation from standing genetic variation to track moving phenotypic optima is theoretically possible nearly in realtime (Matuszewski, Hermisson, \& Kopp, 2015). It is therefore possible that at least some organisms, for example multivoltine species with large population sizes adaptively track their fluctuating environment (Bell, 2010).

This theoretical basis, however, has currently little empirical support from natural populations. While there are on the one hand examples of selective tracking of the fluctuating environment for phenotypic traits (de Villemereuil et al., 2020; Grant \& Grant, 1989; Marrot, Garant, \& Charmantier, 2017) and on the other demonstrations of rapid selectively driven changes on the molecular level (Margres et al., 2017; Yang et al., 2016; Zong, Li, \& Liu, 2021), we are not aware of studies bringing together the observed temporal fitness differences among different phenotypes with the underlying molecular variants in natural populations.

In this study, we took advantage of a natural experiment to tackle the above question. We studied the genomic response of natural population of a non-biting midge to a short-term weather event, in this case a cold snap. This promised the opportunity to study the selective effects of a defined transient event as is typical for the selective regime of fluctuating environments (Bell, 2010). Nonbiting midges of the Chironomid family are widely distributed aquatic insects and have a crucial role in freshwater benthic ecosystems serving as a basis of benthic food webs (Horváth, Móra, Bernáth, \& Kriska, 2011; Oppold et al., 2016; Pfenninger \& Nowak, 2008). Chironomus riparius (Meigen, 1803) is a multivoltine species with up to 15 generations per year in Europe (Oppold et al., 2016). Therefore, the different generations are subjected to widely varying environmental conditions. Accordingly, extensive research on temperature and photoperiod has shown that several traits can and do adapt locally (Waldvogel et al., 2018), and temporally among seasons (Doria, Caliendo, Gerber, \& Pfenninger, 2022; Foucault, Wieser, Waldvogel, Feldmeyer, \& Pfenninger, 2018). But also other factors are known to act as selection pressures on this species (e.g. organic load, Kraak et al. (2000), conductivity, (Pfenninger \& Nowak 2008), nitrogen, (Nemec et al. 2012), temperature, (Nemec et al. 2013) and anthropogenic substances, (Nowak et al. 2009). The high effective and demographic population size $(>1,000,000$, Waldvogel et al. (2018)) and the very high number of offspring per breeding pair (400-800) allows for rapid adaptation (Pfenninger \& Foucault, 2020a). Since genomic resources and parameters are available (Schmidt et al. 2020; Oppold \& Pfenninger 2017) and the species is amenable for evolutionary experiments in the laboratory (Foucault, Wieser, Waldvogel, \& Pfenninger, 2019), the species is increasingly becoming a model for molecular ecology and the emerging field of evolutionary ecotoxicology (Doria, Hannappel, \& Pfenninger, 2022; Doria, Waldvogel, \& Pfenninger, 2021).

In this study we focussed on the following research questions:

- Does normal, transient environmental variation like a cold snap trigger measurable molecular selection in a natural population?

- Are the putatively selected SNP-loci linked to longer survival also under experimental cold exposure conditions?

- Can we link the identified variants to lower level phenotypic changes, i.e. gene expression differences? 
bioRxiv preprint doi: https://doi.org/10.1101/2022.02.10.479864; this version posted February 10,2022 . The copyright holder for this preprint (which was not certified by peer review) is the author/funder, who has granted bioRxiv a license to display the preprint in perpetuity. It is made available under aCC-BY-NC-ND 4.0 International license.

In the course of routine sampling for another project (Pfenninger \& Foucault, 2020b), we sampled larvae of the species Chironomus riparius on Feb. 152018 with a sieve at a single site situated in a small river (Hasselbach, Hessen, Germany $50.167562^{\circ} \mathrm{N}, 9.083542^{\circ} \mathrm{E}$ ) following the protocol of Foucault et al. (2019b). The sampling site is located close to a wastewater treatment plant (Abwasserverband Freigericht) that continuously monitors physical and chemical water parameters, which they generously provided. A few days after the sampling, the air temperature in the region fell substantially below zero for a couple of days, which eventually drove the water temperatures at the sampling site from the long-term average of $9-10^{\circ} \mathrm{C}$ during this time of the year down to about $5^{\circ} \mathrm{C}$ for 2 consecutive days (Figure 1a). We seized the opportunity to obtain another sample of 80 individuals from the same site. Please note that no reproduction takes place in this species at temperatures below $\sim 12-14^{\circ} \mathrm{C}$ and thus the same generation was sampled. A third sample from the same site was obtained in September 2018, about 6-7 generations later (Oppold et al., 2016). The taxonomic identity of the larvae was ascertained by DNA-barcoding of a mitochondrial (COI) and a nuclear locus (L44). Eighty thus identified $C$. riparius were pooled and subjected to Pool-sequencing (see below).

\section{Population genomic analyses}

DNA was extracted for the three pools from the field using the Quiagen blood and tissue extraction kit on pooled samples of 80 larval head capsules, respectively. Integrity and quality of extracted DNA was controlled using electrophoresis, and the DNA concentration for each samples measured with a Qubit fluorimeter (Invitrogen).

Whole genome pool-sequencing was carried out on an Illumina MiSeq with 250bp paired end reads. Reads were trimmed using the wrapper tool Autotrim (Waldvogel et al. 2018) that integrates Trimmomatic (Bolger et al. 2014) for trimming and FastQC (Andrews 2010) for quality control. The trimmed reads were then mapped on the latest $C$. riparius reference genome (Schmidt et al. 2020) using the BWA mem algorithm (Li \& Durbin 2009). Low quality reads were subsequently filtered and SNPs were initially called using Samtools (Li et al. 2009). The pipelines PoPoolation1 v.1.2.2 and PoPoolation2 v.1.201 (Kofler et al. 2011a; Kofler et al. 2011b) were used to call SNPs and remove indels. Allele frequencies for all SNPs with coverage between $15 \mathrm{x}$ and $70 \mathrm{x}$ were estimated with the $\mathrm{R}$ library PoolSeq (Taus et al. 2017).

Selected SNP loci were identified by their allele-frequency change (AFC) larger than expected by sampling variance. Neutral simulations were used to compute false discovery rate q-values $<0.001$ with parameters (number of SNPs, starting allele frequencies matching the ancestral population, sequence coverage, number of generations) matching those of the respective samples. To be conservative, we calculated the drift for one generational passage. As effective population size, we used 15,000, which constitutes a very conservative estimate as well (see Waldvogel et al. (2018)). All calculations and simulations were performed with the R-library poolSeq (Taus et al. 2017).

We used Popoolation 1 to calculate Tajima's D for all non-overlapping $1 \mathrm{~kb}$ windows in the genome. This window size was chosen based on the short average LD (<150 bp) in this species (Pfenninger \& Foucault, 2020b).

\section{Experimental confirmation}

To verify the association of the SNPs to survival under cold stress, we exposed $1604^{\text {th }}$ instar larvae from a laboratory population initially gained from the same population (Pfenninger \& Foucault, $2020 \mathrm{~b}$ ) to $4^{\circ} \mathrm{C}$ until they died or survived for at least 28 days. The individuals were kept separately in $2 \mathrm{~cm}$ well plates with at least $1 \mathrm{~cm}$ water column in a normal fridge. We checked daily whether they were still alive by touching them to see if they still moved. Dead larvae or larvae still alive on the $28^{\text {th }}$ 
bioRxiv preprint doi: https://doi.org/10.1101/2022.02.10.479864; this version posted February 10, 2022. The copyright holder for this preprint (which was not certified by peer review) is the author/funder, who has granted bioRxiv a license to display the preprint in perpetuity. It is made available under aCC-BY-NC-ND 4.0 International license.

day were individually transferred to tubes filled with $70 \%$ alcohol and the day of their death recorded. Of these we chose 30 individuals which died early and 30 individuals which died late or even survived until the end of the $28^{\text {th }}$ days for resequencing.

To link genotype to gene expression we were not able to use the dead individuals from the survival experiment mentioned above. We therefore performed a corresponding short-term experiment exposing another set of $544^{\text {th }}$ instar larvae from the same laboratory population to $4^{\circ} \mathrm{C}$, this time for three days only in order to guarantee for survival. After these three days, 36 living individuals were cut into three pieces on a $-80^{\circ} \mathrm{C}$ cool pad. We cut two segments from a mid-body segment from each larva for subsequent DNA isolation and resequencing, and the rest of the individual was stored at $80^{\circ} \mathrm{C}$ for later RNA-isolation.

\section{DNA/RNA isolation and sequencing}

In total, DNA was isolated from 96 individuals ( 60 from the long-term, and 36 from the short-term $4^{\circ} \mathrm{C}$ exposure experiments) using the Qiagen ${ }^{\circledR}$ blood\&tissue kit. RNA was extracted using the QuickRNA Miniprep kit (Zymo Research). Library preparation and 150bp paired-end sequencing was conducted on a NovaSeq platform.

\section{Identification of individual genotypes}

Quality trimming and mapping of reads was conducted similar to the approach outlined above. Genotypes at the SNP positions identified in the PoolSeq approach were called with bcftools v.1.10.2 (Li, 2011). The genotypes were cross-checked manually for a random sub-sample of individuals with IGV viewer v.2.8.2 (Thorvaldsdóttir, Robinson, \& Mesirov, 2013). We calculated the mean number of potentially adaptive alleles (i.e. those that rose in frequency in the natural population) per variable locus (MNAA) for each resequenced individual as quantitative measure of the multi-locus genotype at the respective loci, thereby assuming an additive genotype-to-phenotype relationship (Sella \& Barton, 2019).

\section{RNA-Seq analysis of cold-exposed individuals and co-expression networks}

Adapters were trimmed and quality checked with TrimGalore (Krueger, 2016). HiSat2 v.2.1.0 (Kim, Paggi, Park, Bennett, \& Salzberg, 2019) was used to map the reads to the $C$. riparius genome (Schmidt et al. 2020). The counts table was created with HTSeq (Anders, Pyl, \& Huber, 2015). To prevent spurious results due to low read counts, we removed genes with less than 10 reads in at least four samples, and samples $\mathrm{C} 4$ and $\mathrm{C} 6$ due to missing allele frequency information. The differential gene expression analysis was conducted using DESeq2 (Love, Huber, \& Anders, 2014) with mean allele frequency as continuous variable(Love et al., 2014)(Love et al. 2014).

To identify networks of co-expressed genes (modules), we constructed a weighted gene coexpression network analysis using the R package WGCNA (Langfelder \& Horvath, 2008), based on the genes that had passed the quality filtering step for the expression analysis $(N=8,264)$. Gene counts were normalized using the varianceStabilizingTransformation function from DESeq2 (Love et al., 2014). Following the WGCNA guidelines, we picked a soft-thresholding power of 6 for adjacency calculation. To associate modules to mean allele frequencies, we first calculated the modules' eigengene using the moduleEigengenes function and tested for module trait correlation using the corPvalueStudent function. To obtain up-to-date annotations, we ran a local blastp (Altschul, Gish, Miller, Myers, \& Lipman, 2008) of the C. riparius proteins versus the non-redundant protein database (version January 2022). We ran Interproscan v.5.53-87.0 (Jones et al., 2014) locally to obtain GO information using the $C$. riparius predicted proteome. The $\mathrm{GO}$ enrichment analysis on genes within the significant module was performed with the R package TopGO (Alexa \& Rahnenführer, 2016), using the 'parentchild' algorithm and the Fishers exact test for significance. 
bioRxiv preprint doi: https://doi.org/10.1101/2022.02 10.479864; this version posted February 10, 2022. The copyright holder for this preprint (which was not certified by peer review) is the author/funder, who has granted bioRxiv a license to display the preprint in perpetuity. It is made available under aCC-BY-NC-ND 4.0 International license.

\section{Association of transcription rates with genotypes}

We used a Bayesian approach (Bååth, 2014) to test for association of genotypes at the identified variable SNP positions and normalised gene expression for genes within $+/-200 \mathrm{~kb}$ on the same scaffold.

\section{Results}

\section{Cold snap and Sampling}

From the $21^{\text {st }}$ of Feb. 2018, the air temperature at the sampling site dropped for 10 consecutive days below zero, with a minimum daily average of $-8^{\circ} \mathrm{C}$ on the $27^{\text {th }}$ of February 2018 . The water temperature, usually fluctuating around $10^{\circ} \mathrm{C}$ in winter, started to fall slowly as well. At the end of this period, the water temperature dropped steeply to $5^{\circ} \mathrm{C}$ for two consecutive days (Figure $1 \mathrm{~A}$ ).

\section{Large allele frequency changes within a single generation}

The allele frequency changes of 19 SNPs between before and after the cold snap could not be explained by sampling variance (Figure 1B). These SNPs were therefore considered as candidates for selection (Table 1). Some of these SNPs occurred on the same scaffold in close spatial proximity to other such SNPs (within 40-750 bp, Table 1). As resequencing data showed, the rising alleles at these SNPs were linked to haplotypes (data not shown). We considered the regions with several SNPs therefore as a single locus and the SNP with the largest AFC was used as marker SNP for these linked haplotypes. Taking this into account, ten loci, each on a different scaffold of the reference genome and thus most likely physically unlinked (Pfenninger \& Foucault, 2020b), were potentially affected by selection. We refer to these loci by their scaffold numbers hereafter (e.g. scaffold227).

The starting frequencies of the rising alleles at these loci before the cold snap were highly variable, spanning the range from undetectably rare (scaffold 424 and scaffold674) to the majority allele (scaffold85, Figure 1C). All candidate alleles rose in frequency by at least about 0.5 (0.467-0.781, Table 1, Figure 1C). In September 2018, the allele frequencies of all but one locus (scaffold227) dropped back towards the level they had before the cold snap event (Figure 1C, Table 3).

The effect of the cold snap on allele frequency spectra varied between candidate loci. Comparing Tajima's $D$ in the $1 \mathrm{~kb}$ windows encompassing the selected regions with the distribution of all $1 \mathrm{~kb}$ windows showed that four selected regions had a Tajima's D in the upper 5\% quantile (scaffold227, scaffold256, scaffold547, scaffold673), indicating balancing selection. One value (scaffold694) was in the lower $5 \%$ tail, suggesting a recent selective sweep. The remaining values were inconspicuous (four) or not calculable (one, Figure 1D).

\section{Validation experiment}

Of the 160 larvae constantly exposed to $4^{\circ} \mathrm{C}$, the first larvae died after 15 days. Mortality on day 21 was extraordinarily high (53 individuals, 34\%). After 28 days, 17 (11\%) larvae were still alive. For seven individuals, the dying day could not be clearly determined. The survival distribution can be found in Supplemental Figure 1.

\section{Genotyping of experimental individuals}

For 59 of the 60 randomly selected individuals from the experiment, resequencing was successful. The individuals could be genotyped on average at 9.02 out of the 10 loci. Two loci were fixed for the rising allele in the experimental sample (Table 2 ) and were thus not further considered.

In the 59 individuals used in the experiment, all candidate alleles had a considerably higher start frequency than in the natural population before the cold snap (Table 3). Nevertheless, among the 
bioRxiv preprint doi: https://doi.org/10.1101/2022.02.10.479864; this version posted February 10, 2022. The copyright holder for this preprint (which was not certified by peer review) is the author/funder, who has granted bioRxiv a license to display the preprint in perpetuity. It is made available under aCC-BY-NC-ND 4.0 International license.

survivors at day 25 , the frequency of all candidate alleles rose between 0.04 and 0.22 in the course of the experiment with moderate $(60.6 \%)$ to very high (98.4\%) posterior probability (Figure $2 \mathrm{~A})$. The mean number of potentially adaptive alleles per variable locus (MNAA) locus ranged between 0.50 and 1.38 among the individuals in the experiment with a mean of 0.98 (s.d. 0.18). The correlation of this value with the length of survival was positive with almost certainty (posterior probability 99.3\%). The association between the variables was moderately strong (most likely estimate of $r=0.33,95 \%$ high density interval between 0.08 and 0.55 , Figure $2 \mathrm{~B}$ ).

\section{Genotype associations with local and global gene expression data}

For 31 individuals, we obtained gene expression data for 11,386 of the 13,449 annotated genes (85\%). Only two loci showed all possible genotypes at the selected loci in the individuals used for transcription analysis (scaffold 227 and scaffold 694). On their scaffolds, the genotypes were strongly associated with the expression levels of one (scaffold 227, Figure 3A), respectively two (scaffold 694, Figure 3B) genes. On scaffold 227, the selected SNP was in an exon of the gene to which is was associated via the genotype specific expression levels. Specifically, the selected allele was associated to a higher expression rate. The gene (scaffold227_gene0.177) is annotated as Cytochrome P450, family 6 (CYP6). The two genes with expression levels strongly associated to genotypes on scaffold 694 were both roughly $100 \mathrm{~kb}$ away from the selected SNP. The first gene, scaffold694_gene0.209 codes for protein (RFT1) that is essential for protein N-glycosylation and also here the positively selected allele was associated with an increase of transcription. In contrast, for the second gene scaffold694_gene0.209, a transmembrane receptor protein tyrosine phosphatase (DEP1), a lower transcription level was associated with the rising allele.

In total, we found the expression of 28 genes to be significantly associated with the MNAA. Nine out of these (32\%) belong to genes of (larval) cuticule proteins, endocuticule proteins or endochitinase. One of the 20 distinct co-expressed modules identified, module-cyan (containing 169 genes), covaried substantially with MNAA (Figure 4A, $r=0.41, p=0.03$ ). A GO-enrichment analysis revealed that gene functions related to fatty acid metabolism were overrepresented in this module (Figure 4b). The cold snap candidate loci themselves were not part of module cyan.

\section{Discussion}

\section{Natural experiment}

In this study, we took advantage of a natural experiment. Following a sampling routine, we coincidently sampled a population pool from a natural $C$. riparius population in late winter just before a cold snap (Pfenninger \& Foucault 2020). Such cold snaps at this time of the year are not the rule in Germany, but also not uncommon. The drop of temperature was marked, but not extreme. Likewise, the duration of the snap was relatively short, at least with regard to the temperature drop in the water. It was therefore an event with the potential to leave a selective mark, but it was not an extreme weather event, let alone a catastrophe. This promised the opportunity to study the selective effects of a defined transient event as is typical for the selective regime of fluctuating environments (Bell, 2010). To infer allele frequency changes potentially driven by selection, we therefore sampled another pool from the same site directly after the cold snap.

C. riparius does not reproduce at temperatures below $10^{\circ} \mathrm{C}$ and larval development is nearly stalled. We can therefore rule out selection based on differential reproductive success over the time-span of the experiment (Reznick, 2016). Any potential selection must have occurred in the same generation by differential mortality of different genotypes. At the same time this meant that genetic drift, defined as sampling variance among generations (Wright, 1948), could not have played a role here, since there was no generational passage involved. We have nevertheless included one generation of 
bioRxiv preprint doi: https://doi.org/10.1101/2022.02.10.479864; this version posted February 10, 2022. The copyright holder for this preprint (which was not certified by peer review) is the author/funder, who has granted bioRxiv a license to display the preprint in perpetuity. It is made available under aCC-BY-NC-ND 4.0 International license.

drift in the calculation of the selection threshold. This threshold is therefore particularly conservative which increases our certainty that the observed allele frequency change beyond this threshold is not due to random processes (Barghi et al., 2019; Hohenlohe, Phillips, \& Cresko, 2010). On the other hand, we have certainly missed smaller, yet selection driven allele frequency changes.

\section{Signs of selection in the natural population}

In total, ten regions in the genome showed signs of selection in the data. Given our rather conservative threshold, which required a large change in allele frequency $(\sim 0.5)$ for detection, we assume that many loci with less pronounced changes remained undetected. The selected haplotypes were very short, often a single SNP, which indicated that they are relatively ancient polymorphisms long since segregating in the population (Nordborg \& Tavaré, 2002) and thus separated by recombination from the background in which they arose. Analysis of Tajima's D for the $1 \mathrm{~kb}$ windows the selected haplotypes resided in showed that nine out of ten had a positive $D$, four even in the upper $5 \%$ quantile. This indicated that the respective polymorphisms could be regularly under differential, balancing selection (Fijarczyk \& Babik, 2015). Given that the presumed selection pressure was a seasonal event, a more or less regularly fluctuating environment with opposite selection pressures in winter and summer appeared plausible. This can lead to a long-term maintenance of the polymorphism under biologically plausible scenarios (Wittmann, Bergland, Feldman, Schmidt, \& Petrov, 2017). Recent works suggested that balancing selection could be more widespread than previously thought (Gloss \& Whiteman, 2016).

The view that seasonal fitness is related to the different alleles at the identified loci was confirmed by the observation that allele frequencies at the potentially selected loci, with one exception (scaffold 227), returned to near their original frequencies a few generations later. This remarkable correlation between the temporal allele frequency trajectories suggested that the same selection pressure with changing signs among seasons was acting. Seasonally selected polymorphisms with correlated allele frequency trajectories were also observed in natural populations of another dipteran species, Drosophila melanogaster (Bergland, Behrman, O'Brien, Schmidt, \& Petrov, 2014; Croze et al., 2017). But also the selection-driven beak variability of Galapagos finches in response to different weather conditions in different years, taking into account the different generation times, are a classic example of very rapid evolutionary adaptations to a variable environment (Boag \& Grant, 1981). Interestingly, we found a strong negative correlation between the start frequency of the selected SNPs and the absolute deviation from neutrality as measured by Tajima's D (Supplemental Figure 2). While theory predicts balanced allele frequencies for overdominance (i.e. by heterozygote advantage (Slatkin \& Muirhead, 1999)), we are not aware of predictions for expected allele frequencies due to balancing selection by temporally changing selection pressures.

\section{Validation experiment}

We observed a substantial variation in survival time in the validation experiment. Compared to the field observations, it took quite a long time ( 15 days) until the first larvae started to die. In the field, the temperature dropped for two days only and this was obviously long enough to trigger a substantial mortality. This discrepancy could have several, mutually not exclusive explanations.

First, the lab population had already quite high allele frequencies at the loci in question. If these loci were indeed responsible for the longer survival, the lab population could have been a priori better protected against the cold exposure. This shift in allele frequency relative to the natural population might be due to random drift in the relatively large but nevertheless demographically necessarily restricted lab population. However, the high allele frequencies could also be a tribute to the practice of storing egg ropes at $4^{\circ} \mathrm{C}$ for a few days prior to initial population set-up and experiments to 
bioRxiv preprint doi: https://doi.org/10.1101/2022.02.10.479864; this version posted February 10, 2022. The copyright holder for this preprint (which was not certified by peer review) is the author/funder, who has granted bioRxiv a license to display the preprint in perpetuity. It is made available under aCC-BY-NC-ND 4.0 International license.

synchronise their development (Foucault et al. 2019). This could have involuntarily preselected the lab population.

Second, the larvae in the experiment came from normal development at benign temperatures $\left(\sim 20^{\circ} \mathrm{C}\right)$ and were well-fed before they were exposed to $4^{\circ} \mathrm{C}$. The larvae in the field likely hatched in autumn and had passed already several months at about $10^{\circ} \mathrm{C}$ before the cold snap set in. The level of internal resources the two groups could draw upon were therefore likely very different and led thus to mortality faster in the natural population. Lastly, it is likely that the lab experiment did not cover all selection factors that were acting in the field. Given the reduced experimental environment, it is almost certain that the set of selection factors acting on the larvae in the field was different from those in the experiment (Pfenninger \& Foucault, 2020a).

The validation experiment confirmed nevertheless the hypothesis that the rising alleles in the natural population did so due to the prolonged cold exposure. This same selection pressure triggered an increase in frequency of the same alleles in the experiment by differential mortality as was observed in nature. This is strong evidence that the candidate alleles indeed played a role in the selection process.

The positive correlation between a straightforward polygenic score (mean number of adaptive alleles per locus involved) and the survival time strongly indicated a relatively simple relation: the more of these alleles were present in an individual, the better were the chances of its longer survival under cold stress. Given the likely involvement of more, but yet unidentified loci, nonlinear interactions among loci and non-quantified environmental components (Sella \& Barton, 2019), the degree of determination found here appeared quite substantial. Additional evidence that these loci are coselected by the same selection pressures came from a strong temporal covariance in allele frequencies, also over longer time scales (Suppl. Figure 3).

\section{Single locus and multi locus genotype associations with gene transcription data}

None of the putatively selected SNPs was within the coding region of an annotated gene. We therefore expected phenotypic effects rather due to changes in the transcription regulation of spatially more or less proximate genes than in structural protein changes.

In an attempt to link the identified loci with basal phenotypic aspects, we sequenced a set of nonlethally cold-exposed individuals for both the genome and the transcriptome. We found transcripts for a substantial proportion of the annotated genes. This is similar to results found in Drosophila (Brown et al., 2014). With a what could be called "inversed eQTL approach" (Gilad, Rifkin, \& Pritchard, 2008; Majewski \& Pastinen, 2011), we explored spatially proximate and thus putative cisinteractions between identified selected sites and gene expression levels. By analysing only loci shown to be involved in phenotypic variation and restricting the spatial extent of the search to a plausible range (Schoenfelder \& Fraser, 2019), we retained sufficient statistical power even with our relatively limited sample size. Since only two of the identified SNP loci (scaffold227 and scaffold694) showed all possible three genotypes in the sample for which both genotype and transcription data was available, the search for associated cis-regulated genes was necessarily restricted to these.

The gene associated to the selected site on scaffold 227 was identified as Cytochrome P450, family 6, a gene-family that is characteristic for insects (Lewis, Watson, \& Lake, 1998). This gene was already several times implicated in the reaction to cold stress(Huang et al., 2017; Lv et al., 2020; Zhang et al., 2015; Zhou, Shan, Tan, Zhang, \& Pang, 2019) with an increased transcription rate under cold conditions. It is therefore plausible that an allele associated with an increased transcription rate as observed here is under positive selection under cold stress conditions. While the selected marker SNP on scaffold 227 was spatially closely linked to the gene with the associated transcription 
bioRxiv preprint doi: https://doi.org/10.1101/2022.02.10.479864; this version posted February 10, 2022. The copyright holder for this preprint (which was not certified by peer review) is the author/funder, who has granted bioRxiv a license to display the preprint in perpetuity. It is made available under aCC-BY-NC-ND 4.0 International license.

regulation, the genes most credibly associated to the SNP genotype on scaffold 694 were both roughly $100 \mathrm{~kb}$ up-, respectively downstream. Both genes were also not the closest neighbouring genes, but the $4^{\text {th }}$, respectively $5^{\text {th }}$ transcribed gene up- respectively downstream on the same scaffold. These observations are compatible with recent models of gene-regulation by long range interactions (Schoenfelder \& Fraser, 2019) that were also observed in insects (Dorsett, 1999). The gene situated upstream was identified as RFT1 homolog. This protein of the endoplasmatic reticulum membrane appears to be necessary for glycolipid translocation and normal protein $\mathrm{N}$-glycosylation, but its exact function is unknown (Gottier et al., 2017). The associated gene downstream was most similar to a transmembrane receptor protein tyrosine phosphatase DEP1. The selected allele was associated to the downregulation of the respective transcripts. We could not find any studies that have previously linked this gene to cold stress.

Using the polygenic score as a proxy for survival time on the individual level was associated to 28 differentially expressed genes. One third of these (nine) belong to (larval) cuticule proteins, endocuticule proteins or endochitinase, suggesting a role for these genes in differential survival. Moreover, the polygenic score as a proxy for survival time on the individual level revealed a moderately strong correlation $(r=0.4)$ to a co-expression module. The co-expression module was statistically enriched for genes involved in fatty acid metabolism. The fatty acid metabolism is known to be crucial for the overwintering of insects (Sinclair \& Marshall, 2018; Storey \& Storey, 2013; Toprak, Hegedus, Doğan, \& Güney, 2020), i.e. under cold stress e.g. by providing the necessary energy storage resources or keeping membranes subtle by changing their fatty acid composition (Overgaard, Sørensen, Petersen, Loeschcke, \& Holmstrup, 2005). There are many examples showing that unsaturated fatty acids increase under cold temperatures in insects (reviewed in Clark and Worland 2008; Teets and Denlinger 2013). Moreover, fat content was one amongst other phenotypes linked to exposure to a new temperature in Drosophila, which also appears to be a polygenic trait (Barghi et al., 2019).

The association suggested that at least some of the identified loci are directly or indirectly involved in trans-regulation of the transcription of these genes. One of the spatially closest genes to a selected site was a histone acetyltransferase p300 on scaffold673. These genes are high level switches that regulate broad scale gene transcription pattern via chromatin remodelling (Tropberger et al., 2013). Amongst many other biological functions, it has been shown that the gene is responsible for the differentiation of fat cells (Gesta, Tseng, \& Kahn, 2007). The transcription level of this gene was significantly associated with the observed genotypes (Supplemental Figure 3), suggesting that a trans-regulated altered transcription of this gene could provide a link between the multilocus genotype and the fatty acid metabolism genes.

This finding allowed to hypothesise a particular physiological trait(s) the identified selected SNPs could, amongst others, contribute to the observed variation in survival time. Individuals with a high polygenic score for the loci involved could accumulate more fat reserves, which increased survival time under prolonged cold conditions. This clearly beneficial fitness effect during the winter season could be reversed in summer, when the accumulation of then unnecessary fat reserves deviates resources from reproduction or increases attractivity for predators. Such a more or less regularly fluctuating selection regime on a polygenic trait could well conform to the theoretical preconditions necessary to maintain the respective polymorphisms over longer periods (Wittmann et al., 2017). Whether there is really a link between the extent of the individual fat reserves and the observed survival time under cold stress conditions, however, remains to be tested, just like a causal relation between the respective multilocus genotype and the regulation of the fatty acid metabolism. However, many more intermediate level traits, e.g. changes in cuticule composition likely contributed to survival under constant cold exposure. 
bioRxiv preprint doi: https://doi.org/10.1101/2022.02 10.479864; this version posted February 10, 2022. The copyright holder for this preprint (which was not certified by peer review) is the author/funder, who has granted bioRxiv a license to display the preprint in perpetuity. It is made available under aCC-BY-NC-ND 4.0 International license.

\section{Conclusions}

In this study we could show that normal, short term environmental variability can lead to measurable natural selection on a polygenic trait in a natural population. Time series population genomic analyses from field samples obviously have the power to pick up such transient signals, even if they consist rather of moderate to strong changes in allele frequencies than in fixation of loci. The observed high temporal correlation of the allele-frequency changes of the loci involved holds the promise that changes in the selective regime may be identified from population genomic time series data. 


\section{References}

Alexa, A., \& Rahnenführer, J. (2016). Gene set enrichment analysis with topGO. R package version 2.24.0.

Altschul, S. F., Gish, W., Miller, W., Myers, E. W., \& Lipman, D. J. (2008). BLAST: Basic Local Alignment Search Tool. Encyclopedia of Genetics, Genomics, Proteomics and Informatics. Dordrecht: Springer Netherlands, 221-1.

Anders, S., Pyl, P. T., \& Huber, W. (2015). HTSeq-A Python framework to work with high-throughput sequencing data. Bioinformatics, 31(2), 166-169.

Bååth, R. (2014). Bayesian first aid: A package that implements Bayesian alternatives to the classical*. test functions in R. Proceedings of UseR, 2014, 2.

Barghi, N., Hermisson, J., \& Schlötterer, C. (2020). Polygenic adaptation: A unifying framework to understand positive selection. Nature Reviews Genetics, 21(12), 769-781.

Barghi, N., Tobler, R., Nolte, V., Jakšić, A. M., Mallard, F., Otte, K. A., ... Schlötterer, C. (2019). Genetic redundancy fuels polygenic adaptation in Drosophila. PLoS Biology, 17(2), e3000128.

Bell, G. (2010). Fluctuating selection: The perpetual renewal of adaptation in variable environments. Philosophical Transactions of the Royal Society B: Biological Sciences, 365(1537), 87-97.

Bergland, A. O., Behrman, E. L., O’Brien, K. R., Schmidt, P. S., \& Petrov, D. A. (2014). Genomic evidence of rapid and stable adaptive oscillations over seasonal time scales in Drosophila. PLoS Genetics, 10(11), e1004775.

Bitter, M. C., Kapsenberg, L., Gattuso, J.-P., \& Pfister, C. A. (2019). Standing genetic variation fuels rapid adaptation to ocean acidification. Nature Communications, 10(1), 1-10.

Boag, P. T., \& Grant, P. R. (1981). Intense natural selection in a population of Darwin's finches (Geospizinae) in the Galapagos. Science, 214(4516), 82-85.

Brown, J. B., Boley, N., Eisman, R., May, G. E., Stoiber, M. H., Duff, M. O., ... Suzuki, A. M. (2014). Diversity and dynamics of the Drosophila transcriptome. Nature, 512(7515), 393-399. 
Croze, M., Wollstein, A., Božičević, V., Živković, D., Stephan, W., \& Hutter, S. (2017). A genome-wide scan for genes under balancing selection in Drosophila melanogaster. BMC Evolutionary Biology, 17(1), 1-12.

de Villemereuil, P., Charmantier, A., Arlt, D., Bize, P., Brekke, P., Brouwer, L., ... Evans, S. R. (2020). Fluctuating optimum and temporally variable selection on breeding date in birds and mammals. Proceedings of the National Academy of Sciences, 117(50), 31969-31978.

Doria, H. B., Caliendo, C., Gerber, S., \& Pfenninger, M. (2022). Photoperiod is an important seasonal selection factor in Chironomus riparius (Diptera: Chironomidae). Biological Journal of the Linnean Society, 135(2), 277-290.

Doria, H. B., Hannappel, P., \& Pfenninger, M. (2022). Whole genome sequencing and RNA-seq evaluation allowed to detect $\mathrm{Cd}$ adaptation footprint in Chironomus riparius. Science of The Total Environment, 152843.

Doria, H. B., Waldvogel, A.-M., \& Pfenninger, M. (2021). Measuring mutagenicity in ecotoxicology: A case study of Cd exposure in Chironomus riparius. Environmental Pollution, 272, 116004.

Dorsett, D. (1999). Distant liaisons: Long-range enhancer-promoter interactions in Drosophila. Current Opinion in Genetics \& Development, 9(5), 505-514.

Fijarczyk, A., \& Babik, W. (2015). Detecting balancing selection in genomes: Limits and prospects. Molecular Ecology, 24(14), 3529-3545.

Foucault, Q., Wieser, A., Waldvogel, A. M., Feldmeyer, B., \& Pfenninger, M. (2018). Rapid adaptation to high temperatures in Chironomus riparius. Ecology and Evolution, 8(24), 12780-12789. doi: 10.1002/ece3.4706

Foucault, Q., Wieser, A., Waldvogel, A.-M., \& Pfenninger, M. (2019). Establishing laboratory cultures and performing ecological and evolutionary experiments with the emerging model species Chironomus riparius. Journal of Applied Entomology, 143(5), 584-592.

Gesta, S., Tseng, Y.-H., \& Kahn, C. R. (2007). Developmental origin of fat: Tracking obesity to its source. Cell, 131(2), 242-256. 
Gilad, Y., Rifkin, S. A., \& Pritchard, J. K. (2008). Revealing the architecture of gene regulation: The promise of eQTL studies. Trends in Genetics, 24(8), 408-415.

Gloss, A. D., \& Whiteman, N. K. (2016). Balancing selection: Walking a tightrope. Current Biology, 26(2), R73-R76.

Gottier, P., Gonzalez-Salgado, A., Menon, A. K., Liu, Y.-C., Acosta-Serrano, A., \& Bütikofer, P. (2017). RFT1 protein affects glycosylphosphatidylinositol (GPI) anchor glycosylation. Journal of Biological Chemistry, 292(3), 1103-1111.

Grant, B. R., \& Grant, P. R. (1989). Natural selection in a population of Darwin's finches. The American Naturalist, 133(3), 377-393.

Hoekstra, H. E., Hoekstra, J. M., Berrigan, D., Vignieri, S. N., Hoang, A., Hill, C. E., ... Kingsolver, J. G. (2001). Strength and tempo of directional selection in the wild. Proceedings of the National Academy of Sciences, 98(16), 9157-9160.

Hohenlohe, P. A., Phillips, P. C., \& Cresko, W. A. (2010). Using population genomics to detect selection in natural populations: Key concepts and methodological considerations. International Journal of Plant Sciences, 171(9), 1059-1071.

Horváth, G., Móra, A., Bernáth, B., \& Kriska, G. (2011). Polarotaxis in non-biting midges: Female chironomids are attracted to horizontally polarized light. Physiology and Behavior, 104(5), 1010-1015. doi: 10.1016/j.physbeh.2011.06.022

Huang, H.-J., Xue, J., Zhuo, J.-C., Cheng, R.-L., Xu, H.-J., \& Zhang, C.-X. (2017). Comparative analysis of the transcriptional responses to low and high temperatures in three rice planthopper species. Molecular Ecology, 26(10), 2726-2737.

Jain, K., \& Stephan, W. (2017). Modes of rapid polygenic adaptation. Molecular Biology and Evolution, 34(12), 3169-3175.

Jones, P., Binns, D., Chang, H.-Y., Fraser, M., Li, W., McAnulla, C., ... Nuka, G. (2014). InterProScan 5: Genome-scale protein function classification. Bioinformatics, 30(9), 1236-1240.

Kim, D., Paggi, J. M., Park, C., Bennett, C., \& Salzberg, S. L. (2019). Graph-based genome alignment and genotyping with HISAT2 and HISAT-genotype. Nature Biotechnology, 37(8), 907-915. 
Kingsolver, J. G., Diamond, S. E., Siepielski, A. M., \& Carlson, S. M. (2012). Synthetic analyses of phenotypic selection in natural populations: Lessons, limitations and future directions. Evolutionary Ecology, 26(5), 1101-1118.

Kingsolver, J. G., Hoekstra, H. E., Hoekstra, J. M., Berrigan, D., Vignieri, S. N., Hill, C. E., ... Beerli, P. (2001). The strength of phenotypic selection in natural populations. The American Naturalist, 157(3), 245-261.

Kingsolver, J. G., \& Pfennig, D. W. (2007). Patterns and power of phenotypic selection in nature. Bioscience, 57(7), 561-572.

Krueger, F. (2016). TrimGalore: A wrapper around Cutadapt and FastQC to consistently apply adapter and quality trimming to FastQ files, with extra functionality for RRBS data. TrimGalore (Accessed on 27 August 2019).

Langfelder, P., \& Horvath, S. (2008). WGCNA: An R package for weighted correlation network analysis. BMC Bioinformatics, 9, 559. doi: 10.1186/1471-2105-9-559

Lewis, D. F. V., Watson, E., \& Lake, B. G. (1998). Evolution of the cytochrome P450 superfamily: Sequence alignments and pharmacogenetics. Mutation Research/Reviews in Mutation Research, 410(3), 245-270.

Li, H. (2011). A statistical framework for SNP calling, mutation discovery, association mapping and population genetical parameter estimation from sequencing data. Bioinformatics, 27(21), 2987-2993.

Love, M. I., Huber, W., \& Anders, S. (2014). Moderated estimation of fold change and dispersion for RNA-seq data with DESeq2. Genome Biology, 15, 550. doi: 10.1186/s13059-014-0550-8 Lv, B., Wang, J., Zhuo, J., Yang, H., Yang, S., Wang, Z., \& Song, Q. (2020). Transcriptome sequencing reveals the effects of cadmium toxicity on the cold tolerance of the wolf spider Pirata subpiraticus. Chemosphere, 254, 126802.

Majewski, J., \& Pastinen, T. (2011). The study of eQTL variations by RNA-seq: From SNPs to phenotypes. Trends in Genetics, 27(2), 72-79. 
Margres, M. J., Wray, K. P., Hassinger, A. T., Ward, M. J., McGivern, J. J., Moriarty Lemmon, E., ... Rokyta, D. R. (2017). Quantity, not quality: Rapid adaptation in a polygenic trait proceeded exclusively through expression differentiation. Molecular Biology and Evolution, 34(12), 3099-3110.

Marrot, P., Garant, D., \& Charmantier, A. (2017). Multiple extreme climatic events strengthen selection for earlier breeding in a wild passerine. Philosophical Transactions of the Royal Society B: Biological Sciences, 372(1723), 20160372.

Matuszewski, S., Hermisson, J., \& Kopp, M. (2015). Catch me if you can: Adaptation from standing genetic variation to a moving phenotypic optimum. Genetics, 200(4), 1255-1274.

Messer, P. W., \& Petrov, D. A. (2013). Population genomics of rapid adaptation by soft selective sweeps. Trends in Ecology \& Evolution, 28(11), 659-669.

Nordborg, M., \& Tavaré, S. (2002). Linkage disequilibrium: What history has to tell us. TRENDS in Genetics, 18(2), 83-90.

Oppold, A. M., Pedrosa, J. A. M., Bálint, M., Diogo, J. B., Ilkova, J., Pestana, J. L. T., \& Pfenninger, M. (2016). Support for the evolutionary speed hypothesis from intraspecific population genetic data in the non-biting midge chironomus riparius. Proceedings of the Royal Society B: Biological Sciences, 283(1825). doi: 10.1098/rspb.2015.2413

Overgaard, J., Sørensen, J. G., Petersen, S. O., Loeschcke, V., \& Holmstrup, M. (2005). Changes in membrane lipid composition following rapid cold hardening in Drosophila melanogaster. Journal of Insect Physiology, 51(11), 1173-1182.

Pfenninger, M., \& Foucault, Q. (2020a). Genomic processes underlying rapid adaptation of a natural Chironomus riparius population to unintendedly applied experimental selection pressures. Molecular Ecology, 29(3), 536-548.

Pfenninger, M., \& Foucault, Q. (2020b, June 16). Quantifying the selection regime in a natural Chironomus riparius population (p. 2020.06.16.154054). p. 2020.06.16.154054. bioRxiv. doi: $10.1101 / 2020.06 .16 .154054$ 
Pfenninger, M., \& Nowak, C. (2008). Reproductive Isolation and Ecological Niche Partition among Larvae of the Morphologically Cryptic Sister Species Chironomus riparius and C. piger. 3(5). doi: 10.1371/journal.pone.0002157

Price, T. D., Grant, P. R., Gibbs, H. L., \& Boag, P. T. (1984). Recurrent patterns of natural selection in a population of Darwin's finches. Nature, 309(5971), 787-789.

Reznick, D. (2016). Hard and soft selection revisited: How evolution by natural selection works in the real world. Journal of Heredity, 107(1), 3-14.

Schoenfelder, S., \& Fraser, P. (2019). Long-range enhancer-promoter contacts in gene expression control. Nature Reviews Genetics, 20(8), 437-455.

Sella, G., \& Barton, N. H. (2019). Thinking about the evolution of complex traits in the era of genomewide association studies. Annual Review of Genomics and Human Genetics, 20, 461-493.

Siepielski, A. M., DiBattista, J. D., \& Carlson, S. M. (2009). It's about time: The temporal dynamics of phenotypic selection in the wild. Ecology Letters, 12(11), 1261-1276.

Siepielski, A. M., DiBattista, J. D., Evans, J. A., \& Carlson, S. M. (2011). Differences in the temporal dynamics of phenotypic selection among fitness components in the wild. Proceedings of the Royal Society B: Biological Sciences, 278(1711), 1572-1580.

Sinclair, B. J., \& Marshall, K. E. (2018). The many roles of fats in overwintering insects. Journal of Experimental Biology, 221(Suppl_1), jeb161836.

Slatkin, M., \& Muirhead, C. A. (1999). Overdominant alleles in a population of variable size. Genetics, 152(2), 775-781.

Storey, K. B., \& Storey, J. M. (2013). Molecular biology of freezing tolerance. Comprehensive Physiology, 3(3), 1283-1308.

Thorvaldsdóttir, H., Robinson, J. T., \& Mesirov, J. P. (2013). Integrative Genomics Viewer (IGV): Highperformance genomics data visualization and exploration. Briefings in Bioinformatics, 14(2), $178-192$.

Toprak, U., Hegedus, D., Doğan, C., \& Güney, G. (2020). A journey into the world of insect lipid metabolism. Archives of Insect Biochemistry and Physiology, 104(2), e21682. 
Tropberger, P., Pott, S., Keller, C., Kamieniarz-Gdula, K., Caron, M., Richter, F., ... Bühler, M. (2013). Regulation of transcription through acetylation of H3K122 on the lateral surface of the histone octamer. Cell, 152(4), 859-872.

Waldvogel, A. M., Wieser, A., Schell, T., Patel, S., Schmidt, H., Hankeln, T., ... Pfenninger, M. (2018). The genomic footprint of climate adaptation in Chironomus riparius. Molecular Ecology, 27(6), 1439-1456. doi: 10.1111/mec.14543

Wittmann, M. J., Bergland, A. O., Feldman, M. W., Schmidt, P. S., \& Petrov, D. A. (2017). Seasonally fluctuating selection can maintain polymorphism at many loci via segregation lift. Proceedings of the National Academy of Sciences, 114(46), E9932-E9941.

Wright, S. (1948). On the roles of directed and random changes in gene frequency in the genetics of populations. Evolution, 279-294.

Yang, J. I., Li, W.-R., Lv, F.-H., He, S.-G., Tian, S.-L., Peng, W.-F., ... Zhang, M. (2016). Whole-genome sequencing of native sheep provides insights into rapid adaptations to extreme environments. Molecular Biology and Evolution, 33(10), 2576-2592.

Zhang, Y., Wu, H., Xie, J., Jiang, R., Deng, C., \& Pang, H. (2015). Transcriptome responses to heat-and cold-stress in ladybirds (Cryptolaemus montrouzieri Mulasnt) analyzed by deep-sequencing. Biological Research, 48(1), 1-14.

Zhou, X.-R., Shan, Y.-M., Tan, Y., Zhang, Z.-R., \& Pang, B.-P. (2019). Comparative analysis of transcriptome responses to cold stress in Galeruca daurica (Coleoptera: Chrysomelidae). Journal of Insect Science, 19(6), 8.

Zong, S.-B., Li, Y.-L., \& Liu, J.-X. (2021). Genomic architecture of rapid parallel adaptation to fresh water in a wild fish. Molecular Biology and Evolution, 38(4), 1317-1329. 
bioRxiv preprint doi: https://doi.org/10.1101/2022.02 10.479864; this version posted February 10 2022. The copyright holder for this preprint (which was not certified by peer review) is the author/funder, who has granted bioRxiv a license to display the preprint in perpetuity. It is made available under aCC-BY-NC-ND 4.0 International license.

\section{Figures}

Figure 1. Field data. A) Air and water temperature curves at the sampling site with sampling dates (grey bars). B) Manhattan plot of the genome-wide SNPs FDR-corrected - $\log _{10} p$ values, contrasting the population pools sampled before and after the cold snap. The horizontal line shows the inferred threshold. C) Allele frequency trajectories at potentially selected loci before and after the cold snap and 6-7 generations later in September 2018. D) Left: Violin-plot of the distribution of Tajima's D for all $177,1851 \mathrm{~kb}$ windows in the genome The mean is indicated by a blue horizontal line, the grey area indicates the $90 \%$ quantile around the mean. The dashed lines mark the beginning of the upper, respectively lower $5 \%$ quantile. Right: Tajima's D for the $1 \mathrm{~kb}$ windows harbouring the putatively selected SNPs. For one window (scaff396) Tajima's D could not be computed.

A

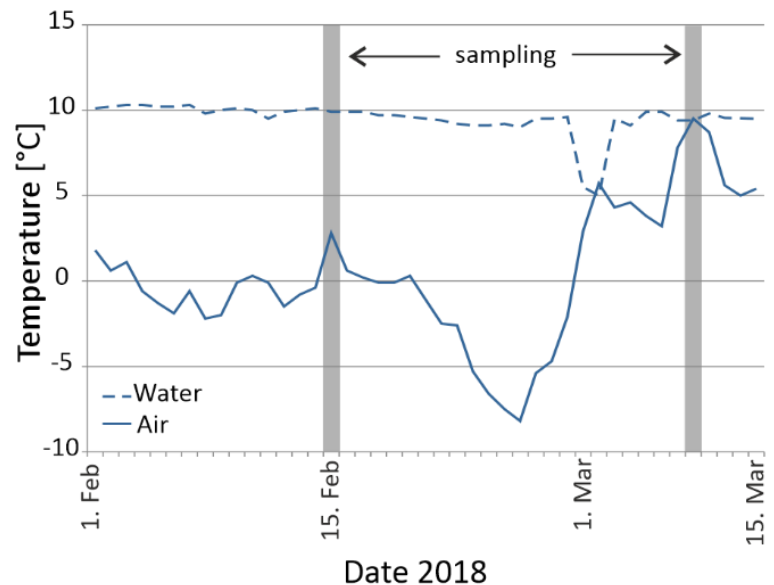

C

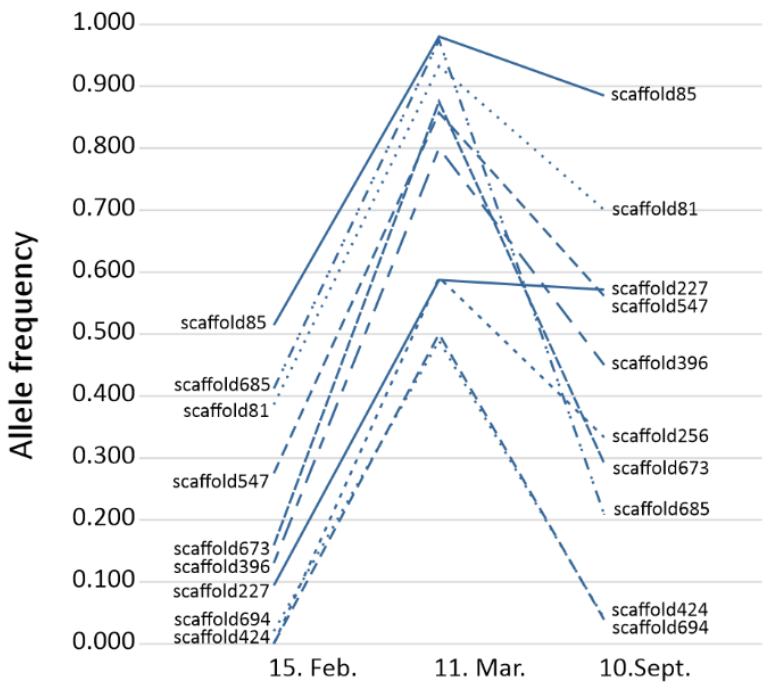

Date 2018

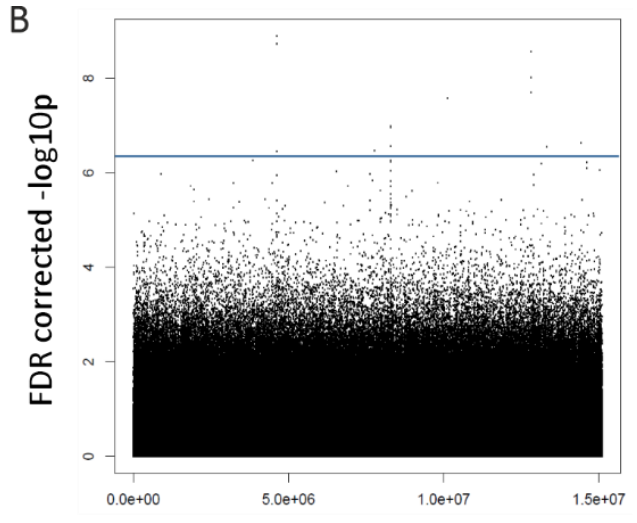

Genome position

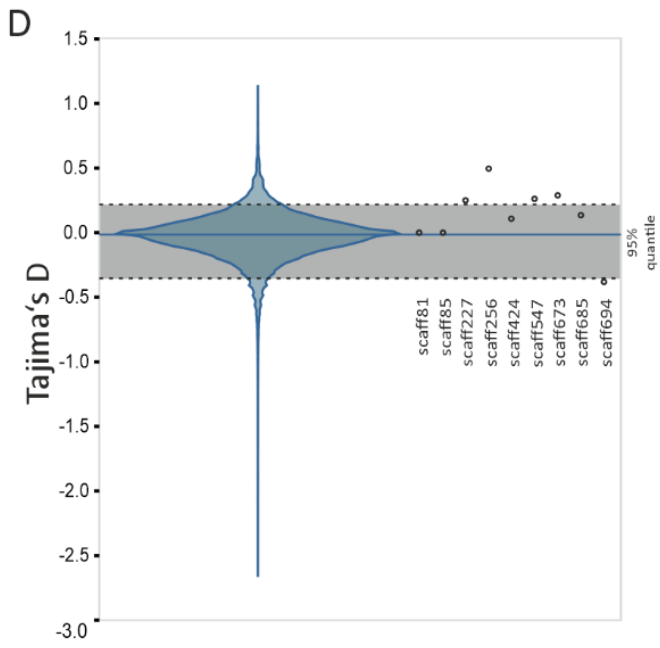

$1 \mathrm{~kb}$ windows with All $1 \mathrm{~kb}$ windows selected SNPs 
bioRxiv preprint doi: https://doi org/10.1101/2022.02 10.479864: this version posted February 10,2022 . The copyright holder for this preprint (which was not certified by peer review) is the author/funder, who has granted bioRxiv a license to display the preprint in perpetuity. It is made available under aCC-BY-NC-ND 4.0 International license.

Figure 2. Experimental data. A) Temporal course of allele frequency changes at polymorphic candidate loci and survival of individuals during the experiment. Shown in blue are the frequency trajectories of the selected alleles in the natural population. The values to the right show the median Bayesian estimate of increase and the associated posterior probability of this value being larger than zero for the respective alleles. B) Bayesian estimate of correlation between the mean number of potentially adaptive alleles per locus and the survival time.
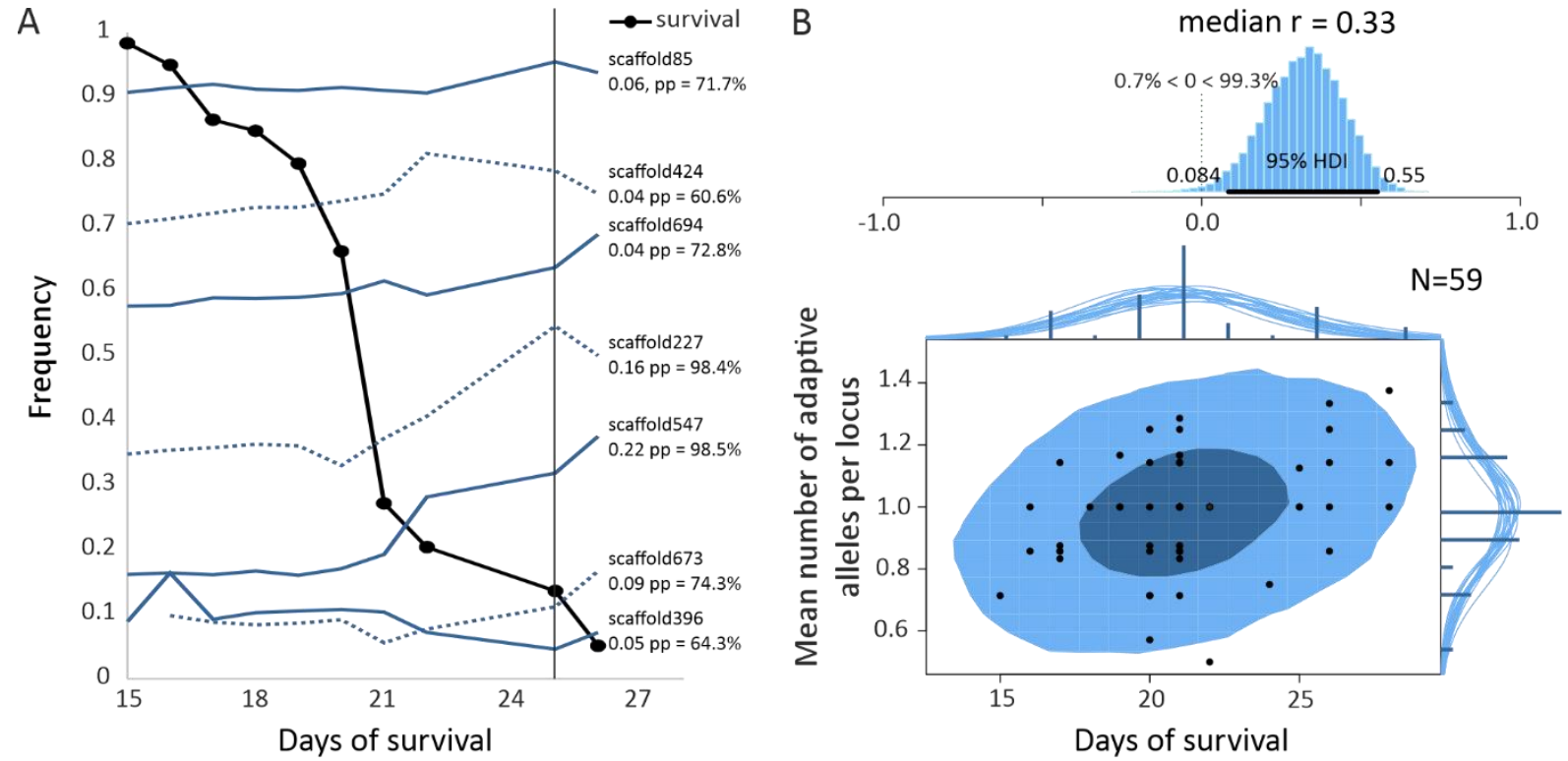
Figure 3. Associations of genotype at selected sites with gene expression levels of genes within $+/-200 \mathrm{~kb}$ on the same scaffold. The position of the selected SNP is indicated with a red arrow. Annotated genes are indicated as blue bars, whose length is proportional to the length of the gene. For genes with expression data available, the genotype specific transcription level is given in a plot. Within plot, the bars represent the standard deviation range of gene expression variation for the possible genotypes, from left to right: homozygous falling allele, heterozygous, homozygous rising allele. Above the panels, the Bayesian statistics for association are given. $r=$ coefficient of association, $\mathrm{HDI}=95 \%$ high density interval, $\mathrm{pp}=$ posterior probability for the association coefficient being larger or smaller than zero, respectively. Highlighted in red are genes with a HDI not comprising zero and pp > $95 \%$. A) scaffold 227 with selected SNP at position 185,498 with a upregulation associated with the rising allele at gene 0.177 . The SNP is positioned in an exon of the gene, B) scaffold 694 with selected SNP at position 289,921. One gene (0.209), situated about $100 \mathrm{~kb}$ from the SNP showed a strong upregulation associated with the rising allele. Another gene (0.262), more than $100 \mathrm{~kb}$ away showed a strong downregulation. 
A)

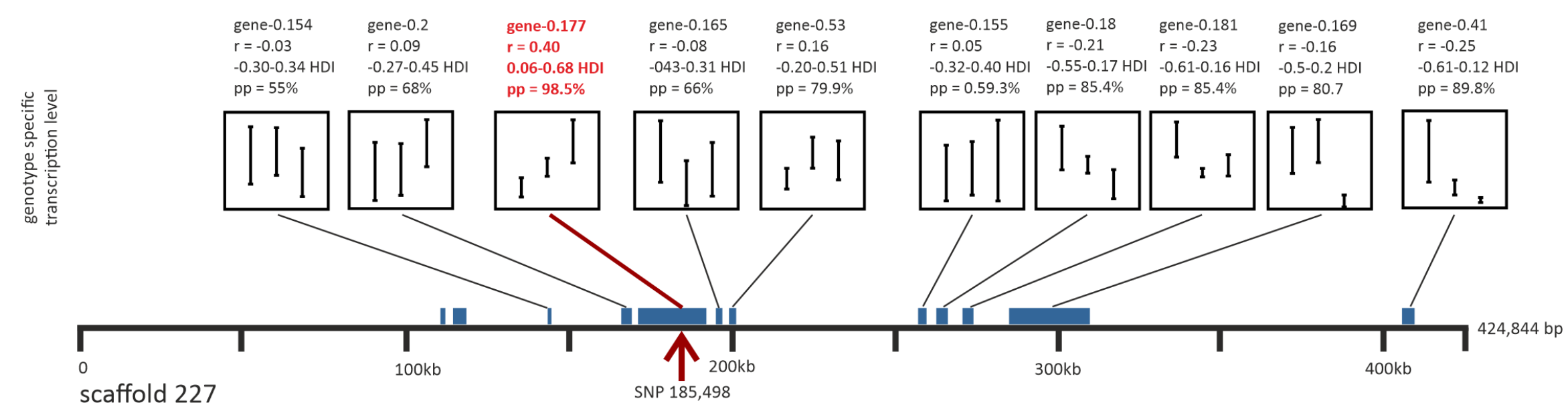

B)

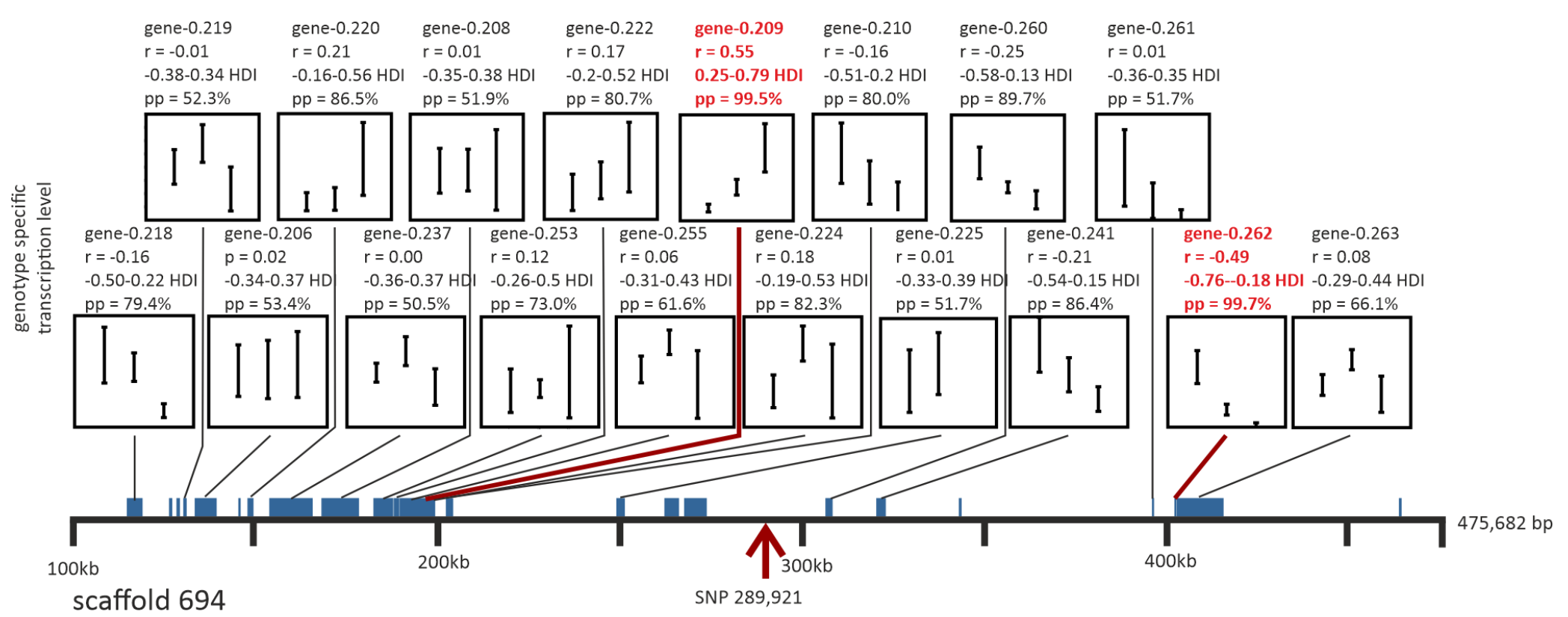



bioRxiv preprint doi: https:/doi org/10.1101/2022.02 10.479864; this version posted February 10 , 2022. The copyright holder for this preprint (which was not certified by peer review) is the author/funder, who has granted bioRxiv a license to display the preprint in perpetuity. It is made available under aCC-BY-NC-ND 4.0 International license.

Figure 4. Association between Mean Number of Adaptive Alleles (MNAA) and gene co-expression modules. A) Correlation of MNAA with inferred gene co-expression modules. The modules carry arbitrary colour names. In the right column, the Pearson correlation coefficient between individual transcription levels and the polygenic score and its probability of being identical to zero (in brackets) for the respective module is given. For immediate visual recognition, the correlation coefficient was also translated into a heatmap from green (-1) over white(0) to red (+1). B) Word-cloud of significantly over-represented GO-terms in the cyan gene co-expression module. The font size is proportional to the number of genes. GO-terms with relation to fatty acid metabolism are underlined.

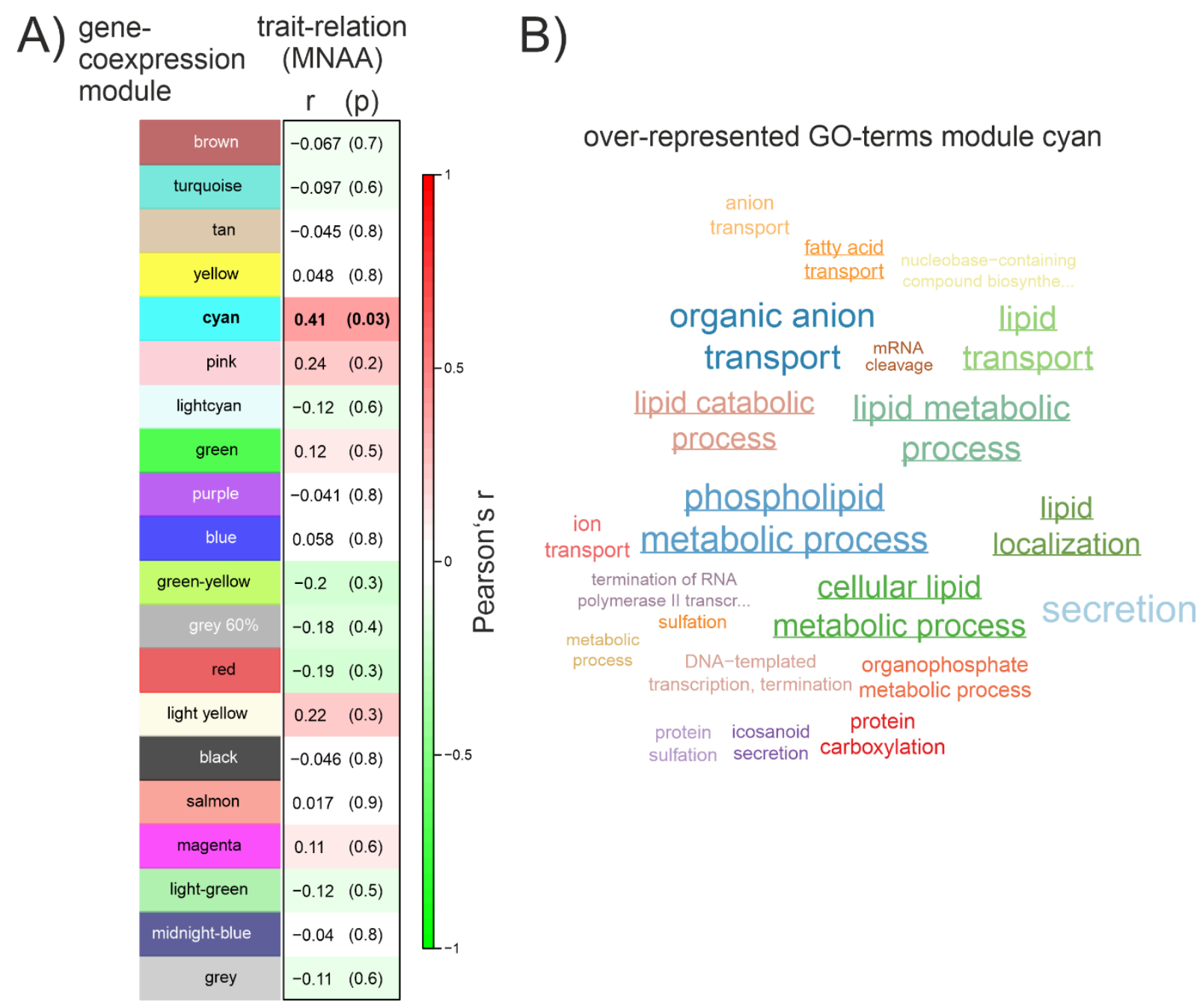


Tables

Table 1. Outlier SNPs in field data.

\begin{tabular}{|c|c|c|c|c|c|c|c|c|c|c|}
\hline Scaffold & position & reference allele & alternate allele & rising allele & start allele freq. & end allele freq. & AFC & $-\log _{10} p$ & $\mathrm{p} \mathrm{fdr}$-corrected & $\begin{array}{l}\text { Tajima's D } \\
1 \mathrm{k}\end{array}$ \\
\hline scaffold85 & 970786 & G & C & G/ref & 0.514 & 0.980 & 0.467 & 6.224 & 0.046 & -0.0162351 \\
\hline scaffold256 & 10257 & C & G & G/alt & 0.000 & 0.591 & 0.591 & 8.734 & 0.001 & 0.4939933 \\
\hline \multirow[t]{2}{*}{ 750 bp } & 10279 & A & G & G/alt & 0.000 & 0.765 & 0.765 & 8.897 & 0.001 & \\
\hline & 11003 & G & C & C/alt & 0.086 & 0.867 & 0.781 & 6.455 & 0.037 & \\
\hline scaffold396 & 51484 & A & G & $A / r e f$ & 0.130 & 0.800 & 0.670 & 6.466 & 0.037 & NA \\
\hline \multirow{4}{*}{$\sim 400 \mathrm{bp}$} & 450623 & G & A & A/alt & 0.000 & 0.500 & 0.500 & 6.561 & 0.035 & \\
\hline & 450627 & A & C & C/alt & 0.000 & 0.534 & 0.534 & 6.967 & 0.019 & \\
\hline & 450663 & C & $T$ & T/alt & 0.000 & 0.500 & 0.500 & 6.236 & 0.046 & \\
\hline & 450800 & C & $T$ & T/alt & 0.000 & 0.533 & 0.533 & 6.993 & 0.019 & \\
\hline scaffold547 & 301068 & $T$ & C & $T /$ ref & 0.275 & 0.857 & 0.582 & 7.582 & 0.006 & 0.2763451 \\
\hline scaffold673 & 15211 & G & $\mathrm{T}$ & T/alt & 0.140 & 0.857 & 0.718 & 8.015 & 0.003 & 0.3208233 \\
\hline
\end{tabular}


Table 2. Nearest genes to potentially selected loci.

\begin{tabular}{|c|c|c|c|c|c|c|}
\hline Scaffold & position & $\begin{array}{l}\text { distance to closest } \\
\text { gene }\end{array}$ & $\begin{array}{l}\text { gene } \\
\text { start }\end{array}$ & $\begin{array}{l}\text { gene } \\
\text { end }\end{array}$ & annotation & Annotation spatially most proximate gene \\
\hline scaffold85 & 970786 & 120 & 970906 & 973122 & scaffold85-snap-gene-1.251 & uncharacterized protein LOC119074020 \\
\hline scaffold256 & 10257 & 1802 & 6914 & 8455 & scaffold256-snap-gene-0.15 & delta-aminolevulinic acid dehydratase-like \\
\hline scaffold396 & 51484 & 24716 & 12088 & 26768 & scaffold396-processed-gene- 0.5 & trichohyalin isoform X3 \\
\hline scaffold547 & 301068 & 1357 & 297539 & 302425 & $\begin{array}{l}\text { scaffold547-processed-gene- } \\
0.68\end{array}$ & protein dachsous \\
\hline scaffold673 & 15257 & 208 & 15465 & 17951 & $\begin{array}{l}\text { scaffold673-augustus-gene- } \\
0.265\end{array}$ & histone acetyltransferase p300 \\
\hline scaffold685 & 402992 & 42771 & 358566 & 360221 & $\begin{array}{l}\text { scaffold685-processed-gene- } \\
0.94\end{array}$ & - \\
\hline
\end{tabular}


Table 3. Allele frequencies in the experiment. AF = allele frequency.

\begin{tabular}{lllllllll}
\hline Scaffold & position & reference allele & alternate allele & rising allele & AF Feb18 & AF Mar18 & AF Sep18 & AF in exp pop \\
\hline scaffold81 & 616771 & T & C & T/ref & 0.386 & 0.932 & 0.700 & 1.000 \\
scaffold85 & 970786 & G & C & G/ref & 0.514 & 0.980 & 0.885 & 0.907 \\
scaffold227 & 185498 & A & G & G/alt & 0.094 & 0.587 & 0.571 & 0.339 \\
scaffold256 & 10257 & C & G & G/alt & 0.000 & 0.591 & 0.333 & 1.000 \\
scaffold396 & 51484 & A & G & A/ref & 0.130 & 0.800 & 0.450 & 0.894 \\
scaffold424 & 450623 & G & A & A/alt & 0.000 & 0.500 & 0.038 & 0.724 \\
scaffold547 & 301068 & T & C & T/ref & 0.275 & 0.857 & 0.561 & 0.839 \\
scaffold673 & 15257 & C & T & T/alt & 0.159 & 0.875 & 0.291 & 0.902 \\
scaffold685 & 402992 & T & C & T/ref & 0.412 & 0.974 & 0.208 & 0.991 \\
scaffold694 & 289921 & T & G & T/ref & 0.020 & 0.489 & 0.041 & 0.414 \\
\hline
\end{tabular}


bioRxiv preprint doi: https://doi.org/10.1101/2022.02 10.479864; this version posted February 10 2022. The copyright holder for this preprint (which was not certified by peer review) is the author/funder, who has granted bioRxiv a license to display the preprint in perpetuity. It is made available under aCC-BY-NC-ND 4.0 International license.

\section{Supplemental Material}

Supplemental Figure 1. Distribution of dying days in the experimental confirmation. The experiment ended on the $28^{\text {th }}$ day. On this day, $11 \%$ of the larvae were still alive.

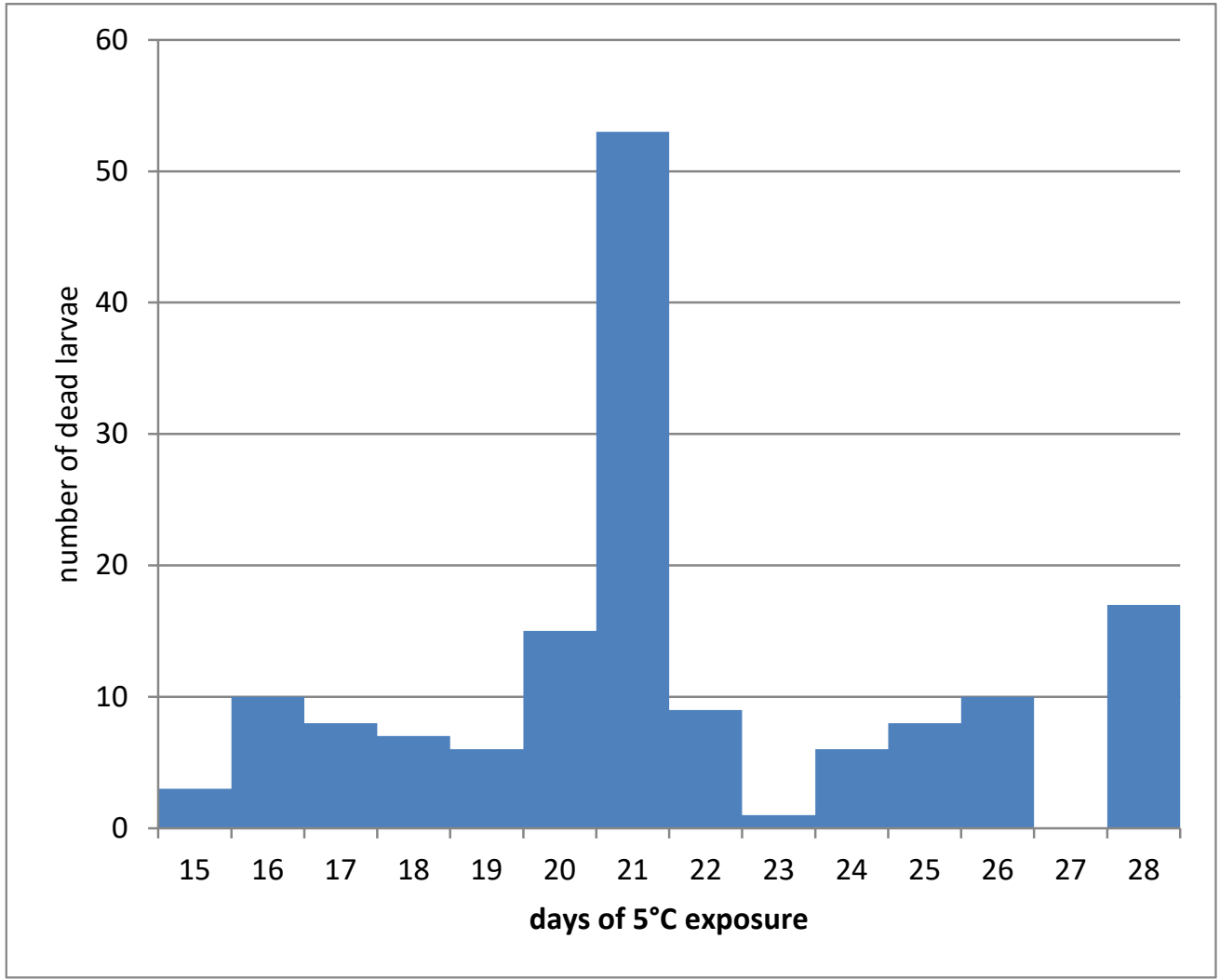


bioRxiv preprint doi: https://doi org/10.1101/2022 $0210.479864 \cdot$ this version posted February 10.2022. The copyright holder for this preprint (which was not certified by peer review) is the author/funder, who has granted bioRxiv a license to display the preprint in perpetuity. It is made available under aCC-BY-NC-ND 4.0 International license.

Supplemental Figure 2. Bayesian analysis of correlation between the starting allele frequency and the absolute deviation from neutrality in Tajima's $D$ for the $1 \mathrm{~kb}$ windows of the selected SNPs.

\section{Correlation $(\rho)$}

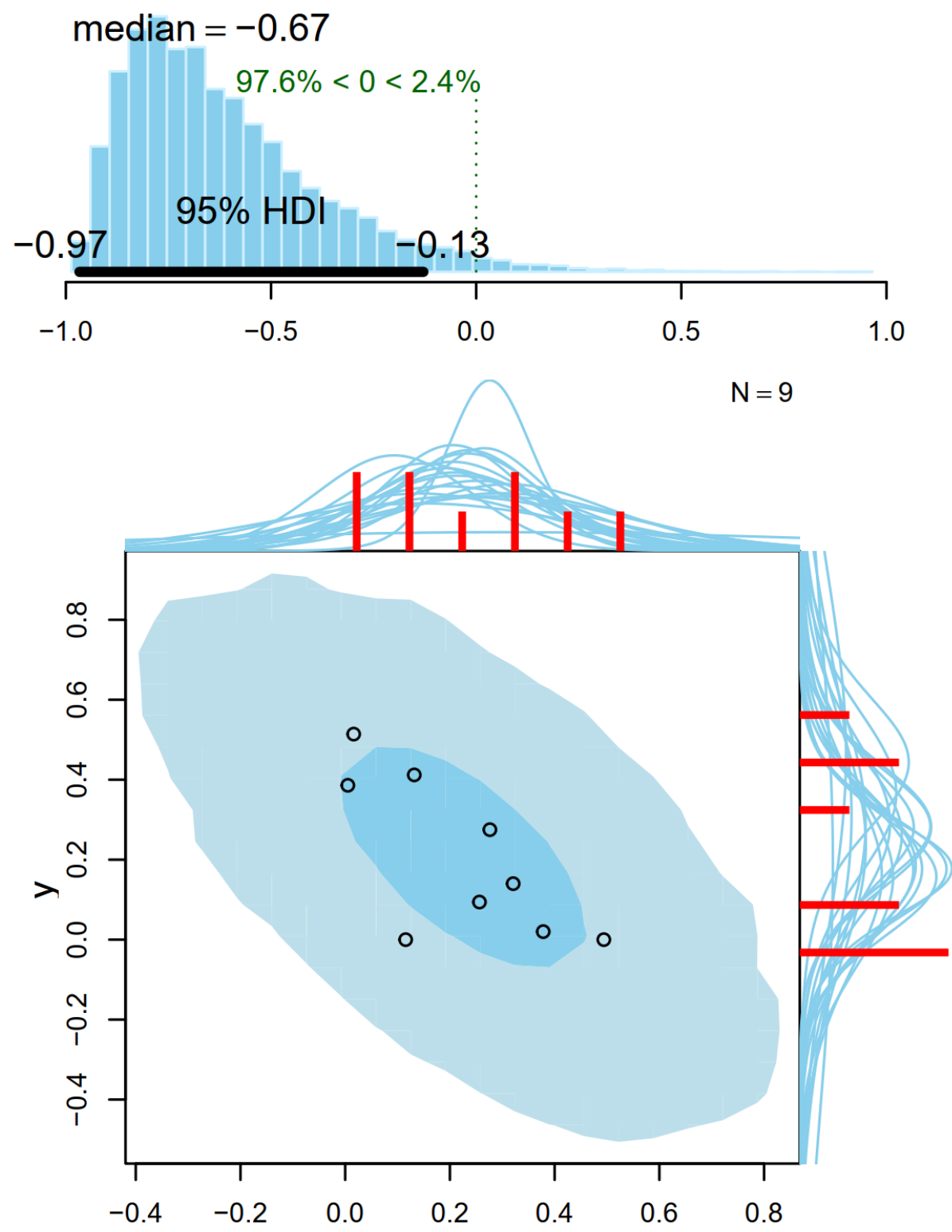


bioRxiv preprint doi: https://doi org/10.1101/2022 02.10 .479864 ; this version posted February 10,2022 . The copyright holder for this preprint (which was not certified by peer review) is the author/funder, who has granted bioRxiv a license to display the preprint in perpetuity. It is made available under aCC-BY-NC-ND 4.0 International license.

Supplemental Figure 3. A) Temporal covariation of allele frequencies at identified loci over time. Shown is the deviation from the mean frequency per locus. B) Difference in mean pairwise correlation coefficient compared to a random sample of 10 SNPs with similar variance located on different scaffolds. Data from Pfenninger, M., \& Foucault, Q. (2020). Quantifying the selection regime in a natural Chironomus riparius population. bioRxiv 2020.06.16.154054.
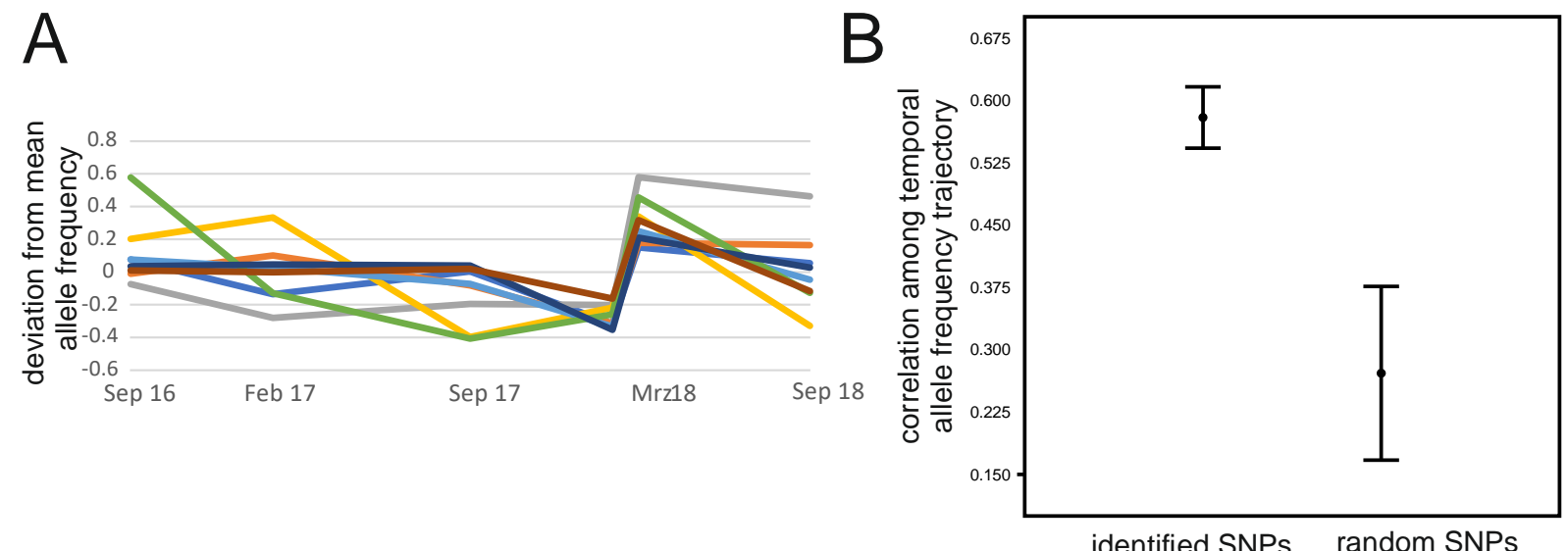

identified SNPs random SNPs 
bioRxiv preprint doi: https://doi org/10.1101/2022 02 10.479864: this version posted February 10,2022 . The copyright holder for this preprint (which was not certified by peer review) is the author/funder, who has granted bioRxiv a license to display the preprint in perpetuity. It is made available under aCC-BY-NC-ND 4.0 International license.

Supplemental Figure 4. Associations of genotype at scaffold673 site with gene expression levels of the closest gene histone acetyltransferase $\mathrm{p} 300$. The difference between the transcription levels among the two observed genotypes was significant (Mann-Whitney test $U=27, p=0.008$ ).

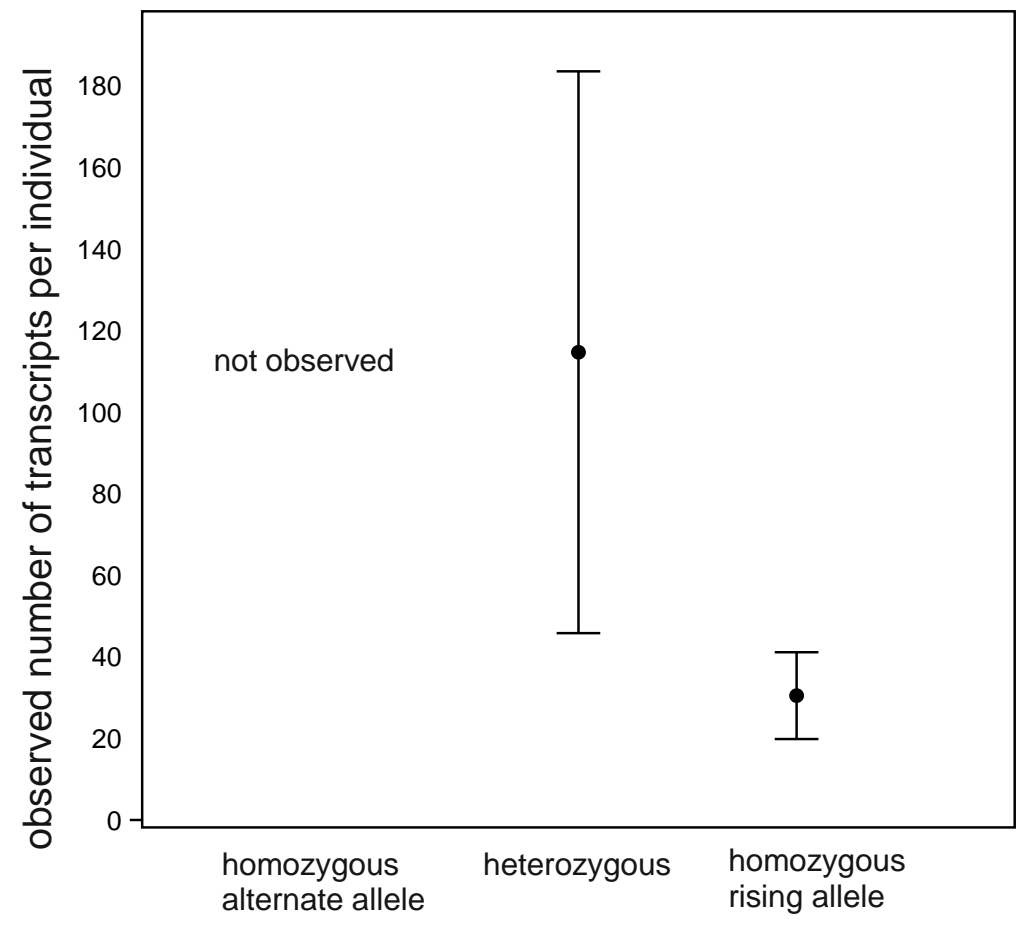

genotype at scaffold673 